\title{
Is This the Right Drug or the Dose for the Management of Onychomycosis?
}

\section{Purva Thatai, Bharti Sapra*}

Department of Pharmaceutical Sciences, Punjabi University, Patiala, India

Keywords: Dermatophytes; Onychomycosis; Fungistatic effect

\section{Introduction}

Onychomycosis is a fungal infection of the toenails and fingernails that results in thickening, discoloration, splitting as well as lifting of the nails from the nail bed. It affects $14 \%$ of the total world population, with more prevalence in elders and diabetics. Both dermatophytes (Trichophyton rubrum or T. mentagrophytes) and nondermatophytes (Scopulariopsis brevicaulis, Aspergillus spp, Fusarium spp, and sometimes Candida $s p p$ ) have been identified as etiologic agents of onychomycosis. The treatment of onychomycosis is known to be challenging since it is a chronic condition, difficult to eradicate and tends to relapse [1]. The pharmacotherapy of onychomycosis involves prolonged systemic or oral antifungal therapy due to slow overturn rate of nail as well as limited blood circulation into the affected nail bed. However, complete cure that involves a clinical cure (normal nail morphology) and mycological cure (both negative microscopy and dermatophyte culture), is often unattainable. In recent years the development of antifungal drugs of second generation (fluconazole, itraconazole, and terbinafine) has produced notable, long-term cure rates with shorter treatment period and improved safety profiles as compared to the first generation antifungal agents. However, different dosage regimens of various antifungal agents have been used by various researchers in clinical trials in order to ensure the complete eradication of the fungal infection in a shorter period with better efficacy.

\section{Antimycotics Used to Treat Onychomycosis}

The attempts have been made since ages to cure onychomycosis. However, there have been a number of failures in treatment and development programs. The prerequisite of treatment of the disease is the penetration of drug to the infected nail bed; however, low permeation rate of drugs necessitates prolonged treatment times.

\section{First generation oral antifungals}

Griseofulvin: Griseofulvin has been in the market since last 40 years and represented a promising advancement in antifungal therapy. The drug was found to be active against growing hyphae. In addition, it inibits nucleic acid synthesis, and arrests fungal cell mitosis in metaphase. However, its effectiveness in onychomycosis is questionable, because of its limited spectrum of activity against dermatophytes only and hence, a longer duration of therapy is required [2]. The fungistatic effect of griseofulvin is believed to be confined in the nail matrix only, hence, only the newly grown nail plate is cleared of the invading fungus. Due to poor retention of the drug in the nail plate after the cessation of oral dosing, a continuous therapy for a prolonged period of time becomes a requisite to maintain the therapeutic level of drug in the nail plate, owing to slow growth of the nail. The prolonged therapy is generally associated with a number of side effects resulting in poor patient compliance, which in turn leads to meager success rate and recurrence of infection [3]. Additionally, the cost of prolonged daily therapy with griseofulvin could be unaffordable.

Ketoconazole: Ketoconazole was the first orally active imidazole having a broad spectrum of activity against dermatophytes as well as non-dermatophytes. However, the prolonged oral delivery of ketoconazole is associated with a number of adverse effects including hypersensitivity reactions, nausea, vomiting, headache, abdominal pain, pruritus, and fever and drug interactions. The major drug interactions of ketoconazole were observed with the drugs metabolized by the cytochrome P-450 system, as well as with certain other drugs (warfarin, rifampin, isoniazid, cyclosporine, terfenadine, cisapride) [4]. Moreover, the prolonged ketoconazole therapy necessitates regular liver function testing that was due to the hepatotoxicity [5]. Hence, the use of ketoconazole for an extended period was restricted prior to the invention of new antifungal agents because of its poor safety and efficacy data.

\section{Second generation oral antifungals}

The second generation of antifungals includes azoles and its derivatives (fluconazole, itraconazole), and allylamine (terbinafine). The azoles and allylamines block the pathway of ergosterol synthesis at different points, which results in difference of implications for efficacy and side effects these drugs Figure 1 and Table 1 summarizes

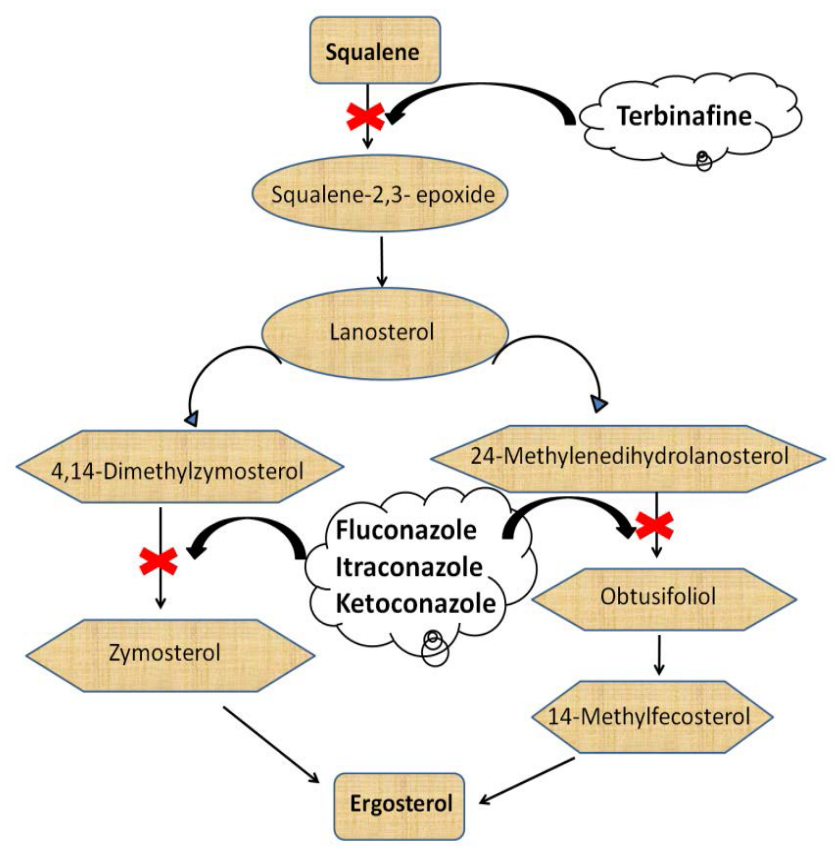

Figure 1: Mechanism of action of second generation anti-fungals.

*Corresponding author: Bharti Sapra, Department of Pharmaceutical Sciences and Drug Research, Punjabi University, Patiala, 147002, Punjab, India, Tel: +9109501019661; E-mail: bhartijatin2000@yahoo.co.in

Received January 21, 2017; Accepted February 11, 2017; Published March 06, 2017

Citation: Thatai P, Sapra B (2017) Is This the Right Drug or the Dose for the Management of Onychomycosis? J Cosmo Trichol 3: 117. doi:10.4172/24719323.1000117

Copyright: ( $\odot 2017$ Thatai P, et al. This is an open-access article distributed under the terms of the Creative Commons Attribution License, which permits unrestricted use, distribution, and reproduction in any medium, provided the original author and source are credited. 


\begin{tabular}{|c|c|c|c|c|c|}
\hline Variable & Griseofulvin & Ketoconazole & Fluconazole & Itraconazole & Terbinafine \\
\hline Route of administration & Oral & Oral / Topical & Oral or intravenous & Oral & Oral / Topical \\
\hline Associated Problems & $\begin{array}{l}\text { Tolerance, longer } \\
\text { treatment length }\end{array}$ & $\begin{array}{c}\text { Toxicity, } \\
\text { Interactions }\end{array}$ & $\begin{array}{l}\text { Interactions, Microbe } \\
\text { resistance }\end{array}$ & Interactions & Adverse Effects \\
\hline Affinity for keratin & Low & High & High & High & High \\
\hline Indicated for skin infection & + & + & + & + & + \\
\hline Indicated for nail infection & - & - & + & + & + \\
\hline $\begin{array}{l}\text { Commercial Dosage } \\
\text { Forms Available }\end{array}$ & $\begin{array}{c}\text { Suspension (125 mg / } \\
\text { 5ml); Tablet (125 mg, } 250 \\
\text { mg, } 500 \mathrm{mg})\end{array}$ & $\begin{array}{c}\text { Cream }(2 \%), \text { Gel }(2 \%) \text {, } \\
\text { Shampoo }(2 \%), \text { Tablet } \\
(250 \mathrm{mg})\end{array}$ & $\begin{array}{c}\text { Suspension }(50 \mathrm{mg} / 5 \mathrm{ml} \\
200 \mathrm{mg} / 5 \mathrm{ml}), \text { Injectable } \\
(200 \mathrm{mg} / 100 \mathrm{ml}, 400 \\
\mathrm{mg} / 200 \mathrm{ml}), \text { Tablet }(50 \mathrm{mg} \text {, } \\
100 \mathrm{mg}, 150 \mathrm{mg}, 200 \mathrm{mg})\end{array}$ & $\begin{array}{l}\text { Capsules (100 mg), Tablet } \\
\text { (200 mg), Solution (10 } \\
\mathrm{mg} / \mathrm{ml})\end{array}$ & $\begin{array}{c}\text { Tablet }(250 \mathrm{mg}) \text {, Gel }(1 \%) \text {, } \\
\text { Cream }(1 \%) \text {, Solution } \\
(1 \%), \text { Spray }(1 \%)\end{array}$ \\
\hline
\end{tabular}

Table 1: Key characteristics of oral antifungal agents.

\begin{tabular}{|c|c|c|c|c|c|c|c|}
\hline Nature of study & $\begin{array}{l}\text { No. of } \\
\text { subjects }\end{array}$ & $\begin{array}{c}\text { Stage of } \\
\text { Onychomycosis }\end{array}$ & Dosage Regimen & $\begin{array}{l}\text { Follow up } \\
\text { period }\end{array}$ & Observation & Remarks & Ref. \\
\hline * & 20 & Severe & $\begin{array}{l}150 \mathrm{mg} \text { once a week for } \\
9.3 \text { months }\end{array}$ & 6 months & $\begin{array}{l}92 \% \text { of toenails were clinically } \\
\text { and mycologicaly free. }\end{array}$ & $\begin{array}{l}\text { Effective in the long-term therapy } \\
\text { of onychomycosis. }\end{array}$ & [10] \\
\hline $\begin{array}{l}\text { Open-labelled, } \\
\text { non-comparative } \\
\text { study }\end{array}$ & 16 & Finger and toenail & $150 \mathrm{mg}$ daily for 6 months & * & $\begin{array}{c}\text { No adverse effect was } \\
\text { observed. }\end{array}$ & $\begin{array}{l}\text { Safe and efficacious, however, } \\
\text { further studies are needed to } \\
\text { determine a cost-effective dosing } \\
\text { regimen. }\end{array}$ & [11] \\
\hline Pilot study & 11 & Toenail of fingernail & $\begin{array}{c}\text { Group I: Eight patients } \\
\text { received } 300 \mathrm{mg} \text { once } \\
\text { weekly } \\
\text { Group II: one patient } \\
\text { received } 200 \mathrm{mg} \text { once } \\
\text { weekly } \\
\text { Group III: two patients } \\
\text { received } 100 \text { or } 200 \mathrm{mg} \\
\text { of fluconazole every other } \\
\text { day. }\end{array}$ & * & $\begin{array}{l}6 \text { patients with toenails involved } \\
\text { were clinically cured after } \\
\text { amean treatment duration of } \\
6 \text { months, and all five patients } \\
\text { with fingernails involved were } \\
\text { cured after } 3.7 \text { months. }\end{array}$ & $\begin{array}{l}\text { Intermittent fluconazole, taken } \\
\text { once weekly or on alternate } \\
\text { days, is a well-tolerated and } \\
\text { efficacious method to treat } \\
\text { onychomycosis. }\end{array}$ & [12] \\
\hline $\begin{array}{l}\text { An open-label, } \\
\text { noncomparative, } \\
\text { multicenter study }\end{array}$ & 114 & Toenail & $\begin{array}{l}\text { 150-mg fluconazole once } \\
\text { per week }\end{array}$ & $\begin{array}{l}1,3 \text { and } 6 \\
\text { months }\end{array}$ & $\begin{array}{c}\text { After } 6 \text { months } \\
\text { Clinical cure: } 54 \% \\
\text { Mycological cure: } 76 \% \text {. }\end{array}$ & $\begin{array}{l}\text { Well tolerated with adverse } \\
\text { events of mild-to-moderate } \\
\text { severity. }\end{array}$ & [13] \\
\hline $\begin{array}{l}\text { A placebo- } \\
\text { controlled, } \\
\text { randomized, } \\
\text { double-blind trial }\end{array}$ & 362 & Finger or toenail & $\begin{array}{c}150,300, \text { and } 450 \mathrm{mg} \\
\text { once weekly for } 6 \text { months }\end{array}$ & * & $\begin{array}{c}\text { Clinical cure amongst all the } \\
\text { doses was } \\
\text { between } 80 \text { and } 90 \% \\
\text { Mycological cure was } 53,59, \\
\text { and } 61 \% \text { for } 150,300 \text { and } 450 \\
\text { mg dose, respectively. }\end{array}$ & $\begin{array}{l}\text { All the regimens were Well } \\
\text { tolerated and incidence and } \\
\text { severity of adverse events were } \\
\text { similar for fluconazole- and } \\
\text { placebo-treated patients. }\end{array}$ & [14] \\
\hline * & 50 & Finger and toenail & $\begin{array}{l}400 \mathrm{mg} \text { once weekly for } \\
12 \text { months }\end{array}$ & * & $\begin{array}{c}21.2 \% \text { patients achieved } \\
\text { mycological eradication, yet } \\
\text { no clinical cure was obtained, } \\
\text { while, } 12.1 \% \text { patients showed } \\
\text { mycological and clinical failure. }\end{array}$ & $\begin{array}{l}\text { High efficacy, good tolerance } \\
\text { and low therapy costs. }\end{array}$ & [15] \\
\hline
\end{tabular}

* Not mentioned

Table 2: Clinical studies of fluconazole carried out by various researchers.

the comparison of some key characteristics of the first generation (griseofulvin and ketoconazole) and second generation (itraconazole, fluconazole, terbinafine) antifungal drugs [6].

Fluconazole: Fluconazole, a water soluble bis-triazole drug, is available commercially in oral and intravenous dosage forms. The drug has high bioavailability (>90\%) which is due to the physiochemical properties of the drug like low molecular weight and high water solubility. The drug is shown to have high affinity towards keratin which was evidenced by its detection in skin within $3 \mathrm{~h}$ of initial therapy. In case of nails, an investigation found the concentration of fluconazole to be 1.3 and $1.8 \mu \mathrm{g} / \mathrm{g}$ on 1 st and 14th day of treatment $(50 \mathrm{mg}$ per day), respectively in healthy male volunteers [7]. In a long term study (6 months) on healthy and diseased nails, the drug was found to retain in the nail plate $(2 \mu \mathrm{g} / \mathrm{g})$ for around 5 months after discontinuation of therapy [8].

Gupta et al. (2013) compared databases of different researchers to study the relationships between fluconazole doses, cure rates and duration of therapy. The findings of the analysis concluded that longer treatments, but not higher weekly fluconazole doses, results in better cure rates for toenail, and possibly fingernail, onychomycosis The lowest dose of $150 \mathrm{mg}$ weekly for more than 6 months was recommended for onychomycosis [9]. Table 2 summarizes clinical studies carried out by various researchers in order to optimize the dosage regimen of fluconazole.

Itraconazole: Itraconazole, a triazole derivative was approved by FDA in 1995 for the management of onychomycosis and is available as capsule and oral solution. The broad spectrum activity, high affinity for keratin and pharmacokinetic profile of itraconazole is accountable for its high efficacy as compared to other antifungals. Although, initially the drug was indicated for the treatment of onychomycosis due to dermatophytes, it has also found to be effective against nondermatophytes. It is rapidly absorbed, attains the peak level within $4 \mathrm{~h}$ and undergoes extensive metabolism by the liver. The observed absolute oral bioavailability of itraconazole is about $56 \%$ [7]. The drug reaches the nail plate within $24 \mathrm{~h}$ of administration and can be observed in the distal part of the nail plate even after one month of initiation of therapy 
[10-16]. The diffusion of the drug into the distal part of the nail occurs via nail bed that is further confirmed due to the presence of two foldhigher drug concentration in subungual nail material than in distal nail clippings of a patient treated for one month. Itraconazole is found to be present in the nail for longer period of time than fluconazole or terbinafine and could be detected even after 9 months of termination of therapy [6]. The oral therapies have usually been recommended as a continuous-dosing regimen for the treatment of onychomycosis. For example, primarily the suggested dose of itraconazole for the management of onychomycosis was $200 \mathrm{mg}$ per day for 3 months. Pharmacokinetic data of itraconazole in the nail bed observed from this study was further utilized to develop an alternative optimal dosage regimen for the treatment of onychomycosis. The treatment course with itraconazole was suggested to be curtailed to only one week interval owing to its rapid penetration and protracted persistence in the nail even after the discontinuation of drug. Moreover, the shorter dosing regimens have merits in terms of being cost effective and higher patient compliance as compared with longer regimens. Therefore, itraconazole has been assessed in intermittent dosing or "pulse therapy" regimens. Pulse therapy with itraconazole embodies dosing for 1 week (pulse) per month for a set number of months [17]. The instances of regimens that have been investigated for safety and efficacy in randomized trials included a three and a four pulse regimen with doses of $200 \mathrm{mg}$ of itraconazole twice daily $[18,19]$ and a two pulse regimen with $200 \mathrm{mg}$ of itraconazole twice daily [17,20-22]. Data from clinical practice and clinical trials indicate that the 1-week pulse regimen of itraconazole is well tolerated and associated with a favorable safety profile [23]. This might lead to the conclusion of using $200 \mathrm{mg}$ one week pulse regimen as efficacious and safer dosage regimen. Table 3 summarizes the various clinical studies involving different regimens of itraconazole and the cure rate obtained.

Terbinafine: Terbinafine is an allylamine derivative reported to have a broad spectrum activity against dermatophytes, certain dimorphic fungi, yeasts and moulds, but has less activity against C. albicans infections. Being lipophilic in nature it gets distributed in tissues like skin, fat, and nails. The drug showed high cure rates (80\%) with $20 \%$ relapse rate and minimal side effects when administered in dermatophytic infections of the toenails for 12 months. In subsequent trials, concise treatment times were evaluated as the mycologic cure was observed early in these studies. In an investigation, $250 \mathrm{mg}$ per day of terbinafine or placebo was given to 85 patients with mycologically proven dermatophyte onychomycosis of the toenails (75 patients) or fingernails (10 patients) for the period of 12 weeks, with long term follow up till 36 weeks. The observations revealed the mycological cure rate of $82 \%$ and $12 \%$ at follow up among terbinafine treated and placebo treated patients, respectively. The clinical cure rates of fingernail infections were observed to be $71 \%$ in terbinafine treated patients at follow up. The findings demonstrated the statistically significant advantage of terbinafine over placebo [24,25].

Subsequently, various studies are summarized in Table 4 that were conducted varying the dosage regimens and treatment periods in order to obtain higher clinical and mycological cure rate. From the above studies [26-30], it could be inferred that pulse therapy was equally efficacious as that of the continuous therapy and in certain cases it was even better. Thus, the former regimen can be preferred owing to the cost effectiveness of the treatment.

Some investigations were carried out in order to compare different available antifungals so as to determine the most reliable and efficacious antifungal agent. Table 5 enlists the comparison of clinical studies of antifungal agents [31-35]. From these findings, terbinafine was found to be more efficacious than other antifungals for the management of onychomycosis.

\section{Topical therapy}

The cure of onychomycosis is known to be strenuous since it is chronic, difficult to obliterate and tends to relapse [36-39]. The pharmacotherapy for onychomycosis widely involves the oral antifungals because their systemic or circulatory distribution allows them to penetrate the nail apparatus and the nail plate. Unfortunately, oral therapy is generally coupled with serious side effects, drug interactions, and high recurrence rates. Therefore, topical therapy is an attractive option due to its non-

\begin{tabular}{|c|c|c|c|c|c|c|c|}
\hline $\begin{array}{l}\text { Nature of } \\
\text { study }\end{array}$ & $\begin{array}{l}\text { No. of } \\
\text { subjects }\end{array}$ & $\begin{array}{l}\text { Site or Stage of } \\
\text { Onychomycosis }\end{array}$ & Dosage Regimen & $\begin{array}{l}\text { Follow up } \\
\text { period }\end{array}$ & Observation & Remarks & Ref. \\
\hline $\begin{array}{l}\text { Multicenter, } \\
\text { randomized, } \\
\text { double blind, } \\
\text { placebo } \\
\text { controlled }\end{array}$ & 73 & Fingernail & $\begin{array}{l}200 \mathrm{mg} \text { twice daily, or } \\
\text { placebo for the first week } \\
\text { of each month for } 2 \\
\text { consecutive months }\end{array}$ & 19 weeks & $\begin{array}{l}\text { Clinical success: } 77 \% \text { in drug } \\
\text { treated vs } 0 \% \text { in placebo } \\
\text { treated patients. } \\
\text { Mycological cure: } 73 \% \text { in drug } \\
\text { treated vs } 13 \% \text { in placebo } \\
\text { treated patients. }\end{array}$ & $\begin{array}{l}\text { Short term pulse therapy is } \\
\text { effective and well tolerated. }\end{array}$ & [17] \\
\hline * & 50 & Toenail & $\begin{array}{c}400 \mathrm{mg} \text { per day d given for } \\
1 \text { week each month for } 3 \text { to } \\
4 \text { months }\end{array}$ & Upto 1 year & $\begin{array}{c}\text { Clinical Cure was } 76 \text { to } 84 \% \text {. } \\
\text { Mycological Cure was } 72-80 \\
\% \text {. }\end{array}$ & $\begin{array}{l}\text { Pulse therapy with itraconazole } \\
\text { is an effective and safe treatment } \\
\text { option for onychomycosis as } \\
\text { the drug persist in nail for a } \\
\text { prolonged time even after the } \\
\text { discontinuation of therapy. }\end{array}$ & [18] \\
\hline $\begin{array}{l}\text { Multicentre, } \\
\text { Double blind, } \\
\text { Parallel group } \\
\text { study }\end{array}$ & 129 & $\begin{array}{l}\text { Distal subungual } \\
\text { onychomycosis of } \\
\text { toenail }\end{array}$ & $\begin{array}{l}\text { Group I: } 200 \text { mg daily for } \\
3 \text { months (continuous } \\
\text { therapy); } \\
\text { Group II: } 400 \text { mg daily } \\
1 \text { week per month for } 3 \\
\text { months (pulse therapy) }\end{array}$ & 9 months & $\begin{array}{l}\text { Clinical success: } 69 \% \text {, in } \\
\text { Group I and } 81 \% \text { in Group II. } \\
\text { Mycological cure: } 66 \text { and } 69 \% \\
\text { in Group I and II, respectively. }\end{array}$ & $\begin{array}{l}\text { Both regimens are effective, safe } \\
\text { and well tolerated. }\end{array}$ & [19] \\
\hline $\begin{array}{l}\text { Multicenter, } \\
\text { randomized, } \\
\text { double blind, } \\
\text { placebo } \\
\text { controlled }\end{array}$ & 214 & Toenail & $\begin{array}{l}200 \mathrm{mg} \text { capsules once } \\
\text { daily for } 12 \text { weeks }\end{array}$ & 9 months & $\begin{array}{c}\text { Clinical success: } 65 \% \text { in } \\
\text { itraconazole treated patients } \\
\text { versus } 3 \% \text { of placebo } \\
\text { treated patients } \\
\text { Mycological cure: } 54 \% \text { in } \\
\text { itraconazole treated patients and } \\
6 \% \text { of placebo treated patients. }\end{array}$ & $\begin{array}{l}\text { Continuous therapy of } \\
\text { itraconazole is highly effective, } \\
\text { well-tolerated therapy for } \\
\text { the management of toenail } \\
\text { onychomycosis. }\end{array}$ & [24] \\
\hline
\end{tabular}




\begin{tabular}{|c|c|c|c|c|c|c|c|}
\hline Nature of study & $\begin{array}{l}\text { No. of } \\
\text { subjects }\end{array}$ & $\begin{array}{l}\text { Site or Stage of } \\
\text { Onychomycosis }\end{array}$ & Dosage Regimen & $\begin{array}{l}\text { Follow up } \\
\text { period }\end{array}$ & Observation & Remarks & Ref. \\
\hline Randomized & 120 & Toenail & $\begin{array}{c}250 \text { mg per day for } 24 \\
\text { weeks }\end{array}$ & Upto 48 weeks & $\begin{array}{c}\text { Cure rates of } 40 \%, 71 \% \\
\text { and } 79 \% \text { were observed } \\
\text { after } 6,12 \text { and } 24 \text { weeks, } \\
\text { respectively. }\end{array}$ & $\begin{array}{l}\text { A treatment period of } 12 \\
\text { weeks is sufficient. }\end{array}$ & [26] \\
\hline * & 65 & $\begin{array}{c}\text { Distal subungual } \\
\text { onychomycosis of the } \\
\text { fingernails or toenails, }\end{array}$ & $250 \mathrm{mg}$ daily for 48 weeks & 6 months & $\begin{array}{l}\text { Mycological and clinical } \\
\text { cure rates were } 70 \% \\
\text { and } 54 \% \text { for C.albicans, } \\
\text { and } 85 \% \text { and } 63 \% \text { for } C \text {. } \\
\text { parapsilosis, respectively. }\end{array}$ & $\begin{array}{l}\text { In addition to } \\
\text { dermatophytes, } \\
\text { terbianfine is also } \\
\text { effective against non- } \\
\text { dermatophytes. }\end{array}$ & [27] \\
\hline $\begin{array}{l}\text { Multicentre, } \\
\text { randomized, double- } \\
\text { blind, }\end{array}$ & 118 & Toenail & $\begin{array}{l}250 \text { mg per day or placebo } \\
\text { for } 12 \text { weeks }\end{array}$ & 48 weeks & Mycological cure: $94 \%$. & $\begin{array}{l}\text { Terbinafine is } \\
\text { effective against non- } \\
\text { dermatophytes. }\end{array}$ & [28] \\
\hline Double blind & 148 & Finger and toenail & $\begin{array}{l}\text { Group I: } 250 \mathrm{mg} \text { per day for } \\
6 \text { weeks, } \\
\text { Group II: } 250 \text { mg per day for } \\
12 \text { weeks. }\end{array}$ & 36 weeks & $\begin{array}{c}\text { Clinical cure: } 45.9 \% \\
\text { Mycological cure: } 58.9 \% \text {. }\end{array}$ & $\begin{array}{l}\text { In toenail mycoses } \\
\text { without visible matrix } \\
\text { involvement, } 6 \text { weeks } \\
\text { treatment of terbinafine } \\
\text { is generally not sufficient, } \\
\text { whereas, fingernail } \\
\text { infections respond well to } \\
\text { this short therapy. }\end{array}$ & [29] \\
\hline $\begin{array}{l}\text { Multicentre, } \\
\text { randomized, double } \\
\text { blind }\end{array}$ & 618 & Distal subungual & $\begin{array}{c}\text { Group I: } 250 \text { mg daily for } 3 \\
\text { months (continuous) } \\
\text { Group II: } 500 \text { mg daily for } \\
1 \text { week per month for } 3 \\
\text { months (pulse) }\end{array}$ & 18 months & $\begin{array}{l}\text { Clinical cure: } 44.6 \% \text { and } \\
29.3 \% \text { in Group I and II, } \\
\text { respectively. } \\
\text { Mycologic cure: } 70.9 \% \\
\text { and } 58.7 \% \text { in Group I and } \\
\text { II, respectively. }\end{array}$ & $\begin{array}{l}\text { Continuous therapy is } \\
\text { superior as compared to } \\
\text { pulse-dose. }\end{array}$ & [30] \\
\hline $\begin{array}{l}\text { Open label, } \\
\text { randomized }\end{array}$ & 504 & Toenail & $\begin{array}{c}250 \text { mg per day for } 12 \text { weeks } \\
\text { with or without aggressive } \\
\text { toenail debridement (at } \\
\text { baseline and weeks } 6,12, \\
\text { and } 24 \text { ) }\end{array}$ & 48 weeks & $\begin{array}{c}\text { Clinical cure: } 41.3 \% \\
\text { Mycological cure: } 64.0 \% \text {. }\end{array}$ & $\begin{array}{l}\text { Debridement showed } \\
\text { no effect on mycologic } \\
\text { outcomes or clinical } \\
\text { effectiveness. }\end{array}$ & [31] \\
\hline * & 55 & Finger and toe nail & $\begin{array}{l}500 \mathrm{mg} \text { per day for } 1 \text { week, } \\
\text { followed by a } 3 \text {-week interval } \\
+ \text { Topical } 1 \% \text { terbinafine } \\
\text { cream was applied daily }\end{array}$ & 1 year & Complete cure: $74.5 \%$. & $\begin{array}{c}\text { Safe and cost effective } \\
\text { regimen. }\end{array}$ & [32] \\
\hline Randomized & 76 & Toenail & $\begin{array}{c}\text { Group I: } 250 \mathrm{mg} \text { daily for } 12 \\
\text { weeks } \\
\text { Group II: } 3 \text { pulses of } \\
\text { terbinafine (each of } 500 \mathrm{mg} \\
\text { daily for a week) repeated } \\
\text { every } 4 \text { weeks }\end{array}$ & 24 weeks & $\begin{array}{l}\text { Clinical success: } 86.8 \% \\
\text { in group I and } 71.1 \% \text { in } \\
\text { Group II. } \\
\text { Mycological cure: } \sim 75 \% \text {. }\end{array}$ & $\begin{array}{l}\text { A pulse dosing schedule } \\
\text { was as efficacious as in a } \\
\text { continuous daily schedule. }\end{array}$ & [33] \\
\hline
\end{tabular}

Table 4: various studies conducted varying the dosage regimens of Terbinafine.

invasiveness, localized effects and obliteration of systemic adverse events and drug interactions [40]. The primary drawback associated with the existing topical antifungal agent is their inability to penetrate into the nail plate resulting in poor mycological and complete cure rates. Hence, the ideal scenario would be to develop the topical agents that have an escalated nail plate penetration as compared to the existing drugs, as well as obviate the systemic uptake [41].

The conventional topical formulations such as creams or ointments are not suitable vehicles for transungual delivery because of the dissimilarity of nail keratin structure with that of the epidermis. Therefore, products specifically suggested for effective transungual therapy are nail lacquers. The primary drugs used as nail lacquers include ciclopirox (8\%) and amorolfine (5\%). After solvent evaporation, the concentration of the drug in lacquer increases and the film on the nail plate surface enables prolonged contact of the drug which enhances both nail hydration and drug diffusion through the affected surface.

Until 2013, only three topical nail lacquers i.e. Penlac (ciclopirox), Ciclopoli $^{\oplus}$ (ciclopirox) and Loceryl ${ }^{\circledR}$ (amorolfine) were approved for the management of onychomycosis in few countries. In 2014, two new topical formulations Kerydin ${ }^{\text {nt }}$ (tavaborole) and Jublia ${ }^{\circ}$ (efinaconazole) which are alcohol based solutions were approved by the USFDA.
Ciclopirox: Ciclopirox, a hydroxy-pyridone derivative exhibits a broad spectrum antifungal activity. The drug has been under investigation since 1973, however, it is being used in the lacquer form since 1990s. In nail lacquer formulation, the drug is present as a free acid, while, in other formulations (cream, suspension, shampoo, gel, solution, powder, globules) it is present as ethanolamine salt and the former is known to be a more active form $[42,43]$. The $8 \%$ concentration of drug in nail lacquer increases to about $35 \%$ after its application, that is significantly higher than the minimal inhibitory concentration (MIC) for T. rubrum, T. mentagrophytes and Candida albicans [44]. The drug is thought to act by chelating trivalent cations $(\mathrm{Fe} 3+$ and $\mathrm{Al} 3+)$ which results in the inhibition of metal-dependent enzymes (cytochromes, catalases, peroxidases), that in turn reduced the transport of ions through pathogen cytoplasmic membranes as well as reduce nutrient intake. The clinical studies revealing the efficacy of $8 \%$ ciclopirox are enlisted in Table 6.

Amorolfine: Amorolfine is a morpholine derivative, reported to exhibit a broad spectrum fungicidal and fungistatic activity [4549]. It acts by inhibiting ergosterol synthesis at two steps i.e by inhibiting delta-14 reductase and delta 7, 8-isomerase. The depletion of ergosterol affects the membrane synthesis of pathogen and causes 
Citation: Thatai P, Sapra B (2017) Is This the Right Drug or the Dose for the Management of Onychomycosis? J Cosmo Trichol 3: 117. doi:10.4172/24719323.1000117

Page 5 of 11

\begin{tabular}{|c|c|c|c|c|c|c|c|}
\hline Nature of study & $\begin{array}{c}\text { No. of } \\
\text { subjects }\end{array}$ & $\begin{array}{l}\text { Site or Stage of } \\
\text { Onychomycosis }\end{array}$ & Dosage Regimen & $\begin{array}{l}\text { Follow up } \\
\text { period }\end{array}$ & Observation & Remarks & Ref. \\
\hline $\begin{array}{l}\text { Double blind, } \\
\text { randomized, } \\
\text { comparative }\end{array}$ & 372 & Toenail & $\begin{array}{l}\text { Group I: Terbinafine; } 250 \\
\text { mg/day (Continuous) } \\
\text { Group II: Itraconazole; } 200 \\
\text { mg/day for } 12 \text { weeks }\end{array}$ & * & $\begin{array}{l}\text { Clinical cure: } 76.2 \% \text { in } \\
\text { Group I and } 58.1 \% \text { in } \\
\text { Group II. Mycological } \\
\text { Cure: } 73 \% \text { in Group I } \\
\text { and } 45.8 \% \text { in group II. }\end{array}$ & $\begin{array}{l}\text { Terbinafine is more } \\
\text { efficacious as compared } \\
\text { to itraconazole. }\end{array}$ & [34] \\
\hline $\begin{array}{l}\text { Double blind, } \\
\text { randomized, } \\
\text { multicenter, } \\
\text { comparative }\end{array}$ & 137 & * & $\begin{array}{l}\text { Group I: Terbinafine ( } 250 \mathrm{mg} \\
\text { daily for } 12 \text { weeks) Group II: } \\
\text { Fluconazole (150 mg once } \\
\text { weekly for } 12 \text { weeks) } \\
\text { Group III: Fluconazole (once } \\
\text { weekly for } \\
24 \text { weeks) }\end{array}$ & * & $\begin{array}{l}\text { Clinical cure: } 67 \%, 21 \% \\
\text { and } 32 \% \text { in Group I, II } \\
\text { and III, respectively. } \\
\text { Mycological cure: } 89 \% \text {, } \\
51 \% \text { and } 49 \% \text {, in Group } \\
\text { I, II and III, respectively. }\end{array}$ & $\begin{array}{c}\text { Terbinafine is more } \\
\text { effective than fluconazole. }\end{array}$ & [35] \\
\hline $\begin{array}{l}\text { Single blind, } \\
\text { randomized, } \\
\text { multicentre, } \\
\text { comparative }\end{array}$ & 190 & Toenail & $\begin{array}{l}\text { Group I: Itraconazole } \\
\text { pulse ( } 200 \text { mg twice daily } \\
\text { for } 1 \text { week) followed by } \\
\text { terbinafine pulse ( } 250 \mathrm{mg} \\
\text { twice daily for } 1 \text { week) } \\
\text { Group II: } 3 \text { or } 4 \text { pulses of } \\
\text { terbinafine }\end{array}$ & 72 weeks & $\begin{array}{l}\text { Clinical cure: } 56.0 \% \text { and } \\
38.9 \% \text { in Group I and II, } \\
\text { respectively. } \\
\text { Mycological cure: } 72.0 \% \\
\text { in Group I versus } 48.9 \% \\
\text { in Group II. }\end{array}$ & $\begin{array}{l}\text { Sequential pulse therapy } \\
\text { with itraconazole and } \\
\text { terbinafine more is } \\
\text { effective and safe. }\end{array}$ & {$[36]$} \\
\hline $\begin{array}{c}\text { Double-blind, } \\
\text { double-dummy study }\end{array}$ & 151 & Toenail & $\begin{array}{l}\text { Group I: Terbinafine } 250 \\
\text { mg/day for } 12 \text { or } 16 \text { weeks } \\
\text { (continuous) } \\
\text { Group II: Itraconazole } 400 \\
\text { mg/day for } 1 \text { week in every } \\
4 \text { weeks for } 12 \text { or } 16 \text { weeks } \\
\text { (intermittent) }\end{array}$ & 54 months & $\begin{array}{l}\text { Mycologic cure: } 46 \% \text { in } \\
\text { Group I and } 13 \% \text { group II. } \\
\text { Mycological Relapse rate: } \\
23 \% \text { and } 53 \% \text { in Group I } \\
\text { and II, respectively. } \\
\text { Clinical relapse rate: } 21 \% \\
\text { and } 48 \% \text { in Group I and } \\
\text { II, respectively. }\end{array}$ & $\begin{array}{l}\text { Continuous terbinafine } \\
\text { provided superior efficacy } \\
\text { and lower rates of } \\
\text { relapse as compared to } \\
\text { intermittent itraconazole. }\end{array}$ & [37] \\
\hline $\begin{array}{l}\text { Open labeled, } \\
\text { randomized, } \\
\text { comparative }\end{array}$ & 50 & $\begin{array}{l}\text { Distal subungual } \\
\text { toenail } \\
\text { onychomycosis }\end{array}$ & $\begin{array}{l}\text { Group I: } 150 \mathrm{mg} \text { fluconazole } \\
\text { once weekly for } 3 \text { months } \\
\text { Group II: } 200 \mathrm{mg} \\
\text { itraconazole twice daily } \\
\text { during the first week of } \\
\text { each month of } 3 \text { month of } \\
\text { treatment period } \\
\text { Group III: } 250 \text { mg per day } \\
\text { terbinafine for } 3 \text { months }\end{array}$ & 6 months & $\begin{array}{c}\text { Clinical cure rates: } \\
81.3 \%, 77.8 \% \text { and } \\
37.5 \% \text { in Group I, II and } \\
\text { III, respectively. } \\
\text { Mycological cure: } 75 \%, \\
61.1 \% \text { and } 31.2 \% \\
\text { in Group I, II and III, } \\
\text { respectively. }\end{array}$ & $\begin{array}{l}\text { Fluconazole was least } \\
\text { effective. With regard to } \\
\text { cost-effectiveness, side } \\
\text { effects and the cure rates, } \\
\text { terbinafine could be the } \\
\text { drug of choice in the } \\
\text { short-term treatment of } \\
\text { toenail onychomycosis. }\end{array}$ & [38] \\
\hline $\begin{array}{l}\text { Long term } \\
\text { Prospective }\end{array}$ & 73 & Toenail & $\begin{array}{c}\text { Group I: Terbinafine } 250 \mathrm{mg} / \\
\text { day (continuous) } \\
\text { Group II: Itraconazole } 400 \\
\text { mg/day for } 1 \text { week per } \\
\text { month }\end{array}$ & 36 months & $\begin{array}{c}\text { Relapse Rate: } 11.9 \% \text { in } \\
\text { Group I and } 35.7 \% \text { in } \\
\text { Group II. }\end{array}$ & $\begin{array}{l}\text { Terbinafine provide better } \\
\text { long-term success than } \\
\text { itraconazole. }\end{array}$ & [39] \\
\hline
\end{tabular}

${ }^{*}$ Not mentioned

Table 5: Comparison of clinical studies of different antifungal agents.

\begin{tabular}{|c|c|c|c|c|c|c|}
\hline $\begin{array}{l}\text { No. of } \\
\text { subjects }\end{array}$ & $\begin{array}{l}\text { Site or Stage of } \\
\text { Onychomycosis }\end{array}$ & Dosage Regimen & $\begin{array}{l}\text { Follow up } \\
\text { period }\end{array}$ & Observation & Remarks & Ref. \\
\hline 460 & $\begin{array}{l}\text { Mild to moderate toe } \\
\text { onychomycosis }\end{array}$ & $\begin{array}{l}\text { Group I: Ciclopirox once daily for } \\
48 \text { weeks } \\
\text { Group II: Vehicle treated in US } \\
\text { and other countries }\end{array}$ & * & $\begin{array}{l}\text { Mycological cure: } \sim 32 \% \text { in Group I and } \\
\sim 10 \% \text { in Group II in US. } \\
\text { In the non-US studies, the mycologic } \\
\text { cure rates ranged from } 46.7 \% \text { to } 85.7 \% \text {. }\end{array}$ & $\begin{array}{l}\text { Excellent safety profile; a } \\
\text { treatment choice with a } \\
\text { favorable benefit-to-risk } \\
\text { ratio. }\end{array}$ & {$[45]$} \\
\hline 460 & $\begin{array}{l}\text { Affected nail area between } \\
20 \% \text { and } 65 \%\end{array}$ & $\begin{array}{c}\text { Group I: Ciclopirox once daily for } \\
48 \text { weeks } \\
\text { Group II: Vehicle }\end{array}$ & 3 months & $\begin{array}{c}\text { Mycologic cure: } 34 \% \text { in Group I and } \\
10 \% \text { in Group II. } \\
\text { Clinical cure: } 8 \% \text { in Group I and } 1 \% \text { in } \\
\text { Group II. }\end{array}$ & Safe and effective. & {$[46]$} \\
\hline 215 & $\begin{array}{l}\text { Finger and toenail } \\
\text { onychomycosis with } \\
\text { diabetes }\end{array}$ & Once daily for 6 months & * & $\begin{array}{l}\text { Ciclopirox nail lacquer reduced the } \\
\text { mean affected nail area from } 64.3 \% \\
\text { at baseline to } 41.2 \% \text { at } 3 \text { months and } \\
25.7 \% \text { at } 6 \text { months. }\end{array}$ & $\begin{array}{c}\text { Safe and effective for } \\
\text { the topical treatment of } \\
\text { onychomycosis in patients } \\
\text { with diabetes. }\end{array}$ & {$[47]$} \\
\hline 49 & $\begin{array}{l}\text { Distal subungual } \\
\text { onychomycosis with } \\
\text { diabetes }\end{array}$ & Once daily for 48 weeks & * & $\begin{array}{l}\text { Clinical cure: } 63.4 \% \\
\text { Mycological cure: } 54.3\end{array}$ & $\begin{array}{l}\text { Safe and effective treatment } \\
\text { for distal subungual } \\
\text { onychomycosis in patients } \\
\text { with diabetes mellitus. }\end{array}$ & {$[48]$} \\
\hline 40 & $\begin{array}{l}\text { Distal and lateral subungual } \\
\text { and lateral subungual } \\
\text { toenail onychomycosis }\end{array}$ & Once daily for 9 months & * & $22 \%$ of the patients had complete cure. & $\begin{array}{l}\text { Low cure rate, can be used } \\
\text { in patients who would not or } \\
\text { cannot tolerate oral therapy. }\end{array}$ & [49] \\
\hline
\end{tabular}

* Not mentioned

Table 6: Clinical studies investigation efficacy of ciclopirox. 
non-typical spherical sterols to accumulate in the fungal cytoplasmic membranes [50] which will in-turn affect the synthesis of membrane. The pharmacokinetic properties of the drug results in high penetration through the nail plate with minimal systemic absorption. Because of the solvent evaporation, the concentration of amorolfine increases from $5 \%$ to $27 \%$ [51]. Because of the pharmacokinetic profile of amorolfine, the drug has good penetration through the nail to the nail bed with minimal systemic absorption. Table 7 summarizes the clinical trials investigating the safety and efficacy of amorlifine in case of onychomycosis.

The findings obtained by different researchers revealed that no significant difference was obtained in cure rates with the application of once weekly or twice weekly of the nail lacquer. Therefore, once weekly use of nail lacquer containing $5 \%$ amorolfine can be preferred owing to patient compliance as well as cost effectiveness.

\section{Combination therapy}

The monotherapy is undoubtedly efficacious in short term; however, a complete and long lasting cure is often unattainable. In those cases, combination therapy has been found to be promising in ameliorating the overall cure rate of onychomycosis [52-55]. The use of combination approach and the application of antifungal drug synergy is a wellknown concept in mycology. The combination of two or more drugs can result in augmented efficacy, rapidity of effects, a broader spectrum of activity and improved patient tolerability [55-59]. The benefits of combination therapy were first shown with griseofulvin as the standard therapy for the treatment of onychomycosis (due to dermatophytes) for the last 30 years. More recently, combinations of newer generation of drugs have been shown to have greater efficacy than griseofulvin (Table 8).

\section{Newer topical solutions}

There have been a number of unsuccessful development programs over the past decade as researchers endeavored to formulate antifungals that manifested in vitro activity against the common pathogens causing onychomycosis [60-63]. The discovery of new chemical entities exhibiting a broad spectrum of activity against multiple relevant fungal pathogens has led to progressive development of the dosage form and formulation for the treatment of different fungal diseases including onychomycosis $[64,65]$.

The newer antifungal agents among azoles are efinaconazole, luliconazole, albaconazole, posaconazole and revuconazole, among benzoxaboroles is tevaborole and among allyl amines are NB-002 and NB-00X. Few amongst them are already commercially available, however, few of them are in different clinical phases.

Efinaconazole: Efinaconazole (Jublia ${ }^{\circ}$ and Clenafin $^{\circ}$ ) is an emerging antifungal therapy for the topical treatment of onychomycosis. Efinaconazole is an inhibitor of sterol $14 \alpha$-demethylase and possess broad spectrum antifungal activity against dermatophytes, yeasts and non-dermatophyte molds. It is approved for use in Canada and the USA as a $10 \%$ topical solution for the treatment of onychomycosis $[66,67]$.

The physicochemical properties and antifungal activity of drug and the nature of the vehicle are believed to contribute in favorable therapeutic outcomes of onychomycosis. Efinaconazole (10\%) solution is found to be significantly more active than amorolfine and ciclopirox lacquers against dermatophytes in an in vivo guinea pig model. The keratin-bound efinaconazole was observed to release more rapidly after repeated washings ( $85.7 \%$ bound; $46 \%$ released) as compared to amorolfine ( $98.1 \%$ bound, $6.9 \%$ released) and ciclopirox $(99.3 \%$ bound, $2.4 \%$ released) due to its lower affinity towards keratin [67]. The commercial formulation of the drug (solution) comprises of alcohol, lipophilic esters, and cyclomethicone. These components help to create a low surface tension which seems to be ideal for application to the surface of dry nail plate $[68,69]$. Unlike previous lacquer-based treatments, such as ciclopirox (8\%), efinaconazole (10\%) solution is effective without concomitant nail debridement between the applications. The studies, including investigation of efinaconazole $10 \%$ solution are summarized in Table 9 .

Luliconazole: Luliconazole is a topical imidazole that has been tested in Phase I/II clinical trials. It is approved for the treatment of dermatomycoses in Japan [70]. A new set of clinical trials has been initiated to investigate luliconazole for the treatment of onychomycosis

\begin{tabular}{|c|c|c|c|c|c|c|}
\hline No. of subjects & $\begin{array}{l}\text { Site or Stage of } \\
\text { Onychomycosis }\end{array}$ & Dosage Regimen & $\begin{array}{l}\text { Follow up } \\
\text { period }\end{array}$ & Observation & Remarks & Ref. \\
\hline 554 & Finger and Toenails & $\begin{array}{l}\text { Group I: Twice weekly for } 6 \\
\text { months } \\
\text { Group II: Once weekly for } 6 \\
\text { months }\end{array}$ & 3 months & $\begin{array}{c}\text { Clinical cure: } 52 \% \text { and } 46.1 \% \\
\text { in Group I and II, respectively. } \\
\text { Mycological cure: } 79.2 \\
\text { and } 77.2 \text { in Group I and II, } \\
\text { respectively. }\end{array}$ & $\begin{array}{l}\text { No statistically significant } \\
\text { difference between the two } \\
\text { groups. }\end{array}$ & [52] \\
\hline 157 & $\begin{array}{l}\text { More than } 80 \% \text { of the } \\
\text { surface area of the nail } \\
\text { affected }\end{array}$ & $\begin{array}{l}\text { Group I: } 2 \% \text { amorolfine once } \\
\text { weekly for } 6 \text { months } \\
\text { Group II: } 5 \% \text { amorolfine once } \\
\text { weekly for } 6 \text { months }\end{array}$ & 3 months & $\begin{array}{l}\% \text { Cure: } 12 \% \text { and } 38 \% \text { in } \\
\text { Group I and II, respectively. }\end{array}$ & $\begin{array}{l}5 \% \text { nail lacquer is significantly } \\
\text { more effective than } 2 \% \text { of nail } \\
\text { lacquer. }\end{array}$ & [53] \\
\hline 727 & Finger or toenail & $\begin{array}{l}\text { Group I: } 2 \% \text { amorolfine once } \\
\text { weekly for } 6 \text { months } \\
\text { Group II: } 2 \% \text { amorolfine twice } \\
\text { weekly for } 6 \text { months } \\
\text { Group III: } 5 \% \text { amorolfine once } \\
\text { weekly for } 6 \text { months } \\
\text { Group IV: } 5 \% \text { amorolfine twice } \\
\text { weekly for } 6 \text { months }\end{array}$ & 3 months & $\begin{array}{c}\% \text { Cure achieved: } 16.3 \%, \\
35.8 \%, 45.6 \% \text { and } 51.8 \% \\
\text { in Group I, II, III and IV, } \\
\text { respectively. }\end{array}$ & $\begin{array}{c}\text { Amorolfine in the form of a } 5 \% \\
\text { lacquer administered either } \\
\text { once or twice weekly proved } \\
\text { more effective. }\end{array}$ & [54] \\
\hline 456 & Finger and toenails & $\begin{array}{l}\text { Group I: } 5 \% \text { amorolfine once } \\
\text { weekly for } 6 \text { months } \\
\text { Group I: } 5 \% \text { amorolfine twice } \\
\text { weekly for } 6 \text { months }\end{array}$ & 3 months & $\begin{array}{l}\text { Overall cure rate: } 46 \% \text { and } \\
54.2 \% \text { in Group I and II, } \\
\text { respectively. } \\
\text { Mycological cure rate: } 70.6 \\
\text { and } 76.1 \% \text { in Group I and II, } \\
\text { respectively. }\end{array}$ & $\begin{array}{c}\text { No significant difference in } \\
\text { cure rates. }\end{array}$ & [55] \\
\hline
\end{tabular}

Table 7: Clinical trials investigating the safety and efficacy of amorlifine 
Citation: Thatai P, Sapra B (2017) Is This the Right Drug or the Dose for the Management of Onychomycosis? J Cosmo Trichol 3: 117. doi:10.4172/24719323.1000117

Page 7 of 11

\begin{tabular}{|c|c|c|c|c|c|c|c|}
\hline Combination & $\begin{array}{c}\text { No. of } \\
\text { subjects }\end{array}$ & $\begin{array}{l}\text { Site or Stage of } \\
\text { Onychomycosis }\end{array}$ & Dosage Regimen & $\begin{array}{c}\text { Follow } \\
\text { up period }\end{array}$ & Observation & Remarks & Ref. \\
\hline $\begin{array}{l}\text { Topical } \\
\text { tioconazole and } \\
\text { oral Griseofulvin }\end{array}$ & 10 & Toenail & $\begin{array}{c}\text { Group I: } 500 \mathrm{mg} \text { griseofulvin twice } \\
\text { daily for one year + Tioconazole }(28 \%) \\
\text { solution to be applied twice daily } \\
\text { Group II: } 500 \mathrm{mg} \text { griseofulvin twice daily } \\
\text { for one year + Placebo solution to be } \\
\text { applied twice daily }\end{array}$ & * & $\begin{array}{l}\text { Complete clinical cure: } 69 \% \text { and } 41 \% \\
\text { in Group I and II, respectively. }\end{array}$ & $\begin{array}{c}\text { Combinational therapy } \\
\text { produced a more rapid } \\
\text { and complete response } \\
\text { than when using the oral } \\
\text { drug alone. }\end{array}$ & {$[56]$} \\
\hline $\begin{array}{c}\text { Oral } \\
\text { Gresiofulvin + } \\
\text { oral Itraconazole }\end{array}$ & 90 & Toenail & $\begin{array}{l}\text { Group I: Itraconazole (100mg per day) } \\
\text { Group II: Griseofulvin ( } 500 \text { mg daily) } \\
\text { Each group was divided into three } \\
\text { subgroups that received different } \\
\text { topical treatment: antimycotic cream } \\
\text { (isoconazole } 1 \% \text { ), keratolytic cream } \\
\text { (urea } 40 \% \text { ), or placebo cream. }\end{array}$ & * & $\begin{array}{l}\text { The itraconazole group showed } \\
\text { complete clearance in combination } \\
\text { with isoconazole cream in } 73.3 \% \\
\text { patients, in combination with } \\
\text { keratolytic cream in } 78.5 \% \text { patients } \\
\text { and in combination with placebo } \\
\text { cream in } 91.6 \% \text { patients. } \\
\text { The griseofulvin group showed } \\
\text { complete clearance in combination } \\
\text { with isoconazole cream in } 46.1 \% \\
\text { patients, in combination with } \\
\text { keratolytic cream in } 42.8 \% \text { patients, } \\
\text { and in combination with placebo } \\
\text { cream in } 26.6 \% \text { patients. }\end{array}$ & $\begin{array}{l}\text { The itraconazole group } \\
\text { showed better results } \\
\text { compared with the } \\
\text { griseofulvin group. }\end{array}$ & {$[57]$} \\
\hline $\begin{array}{c}\text { Topical } \\
\text { amorolfine and } \\
\text { oral terbinafine }\end{array}$ & 147 & $\begin{array}{c}\text { Toenail } \\
\text { onychomycosis } \\
\text { with matrix area } \\
\text { involvement }\end{array}$ & $\begin{array}{l}\text { Group I: Oral terbinafine } 250 \mathrm{mg} \text { once } \\
\text { daily for } 6 \text { months }+15 \text { months of once- } \\
\text { weekly topical amorolfine lacquer } \\
\text { Group II: Oral terbinafine once daily for } \\
12 \text { months }+15 \text { months of once-weekly } \\
\text { topical amorolfine lacquer Group III: } \\
\text { Terbinafine monotherapy for } 12 \text { weeks }\end{array}$ & $\begin{array}{c}18 \\
\text { months }\end{array}$ & $\begin{array}{l}\text { Complete cure rate: } 44 \%, 72.3 \% \\
\text { and } 37.55 \text { in Group I, II and III, } \\
\text { respectively. } \\
\text { Mycological cure: } 35 \%, 27.5 \% \\
\text { and } 17.1 \% \text { in Group I, II and III, } \\
\text { respectively. }\end{array}$ & $\begin{array}{l}\text { Combination therapy } \\
\text { proved to be effective in } \\
\text { severe onychomycosis. }\end{array}$ & {$[58]$} \\
\hline $\begin{array}{c}\text { Topical } \\
\text { amorolfine }+ \\
\text { oral terbinafine }\end{array}$ & 147 & $\begin{array}{c}\text { Toenail } \\
\text { onychomycosis } \\
\text { with matrix area } \\
\text { involvement }\end{array}$ & $\begin{array}{l}\text { Group I: Oral terbinafine } 250 \mathrm{mg} \text { once } \\
\text { daily for } 6 \text { months }+15 \text { months of once- } \\
\text { weekly topical amorolfine lacquer } \\
\text { Group II: Oral terbinafine once daily for } \\
12 \text { months }+15 \text { months of once-weekly } \\
\text { topical amorolfine lacquer Group III: } \\
\text { Terbinafine monotherapy for } 12 \text { weeks }\end{array}$ & $\begin{array}{c}18 \\
\text { months }\end{array}$ & $\begin{array}{l}\text { Mycological cure: } 35 \%, 27.5 \% \\
\text { and } 17.1 \% \text { in Group I, II and III, } \\
\text { respectively. } \\
\text { Overall cure: } 44 \%, 72.3 \% \text { and } 37.5 \% \\
\text { in Group I, II and III, respectively. }\end{array}$ & $\begin{array}{l}\text { Combination therapy } \\
\text { regime with oral and } \\
\text { systemic treatment } \\
\text { was superior in } \\
\text { efficacy as compare to } \\
\text { monotherapy. }\end{array}$ & [59] \\
\hline $\begin{array}{c}\text { Topical } \\
\text { amorolfine and } \\
\text { oral itraconazole }\end{array}$ & 131 & $\begin{array}{c}\text { Toenail } \\
\text { onychomycosis } \\
\text { with matrix area } \\
\text { involvement }\end{array}$ & $\begin{array}{c}\text { Group I: Amorolfine } 5 \% \text { nail lacquer } \\
\text { once weekly for } 24 \text { weeks }+200 \mathrm{mg} \\
\text { itraconazole once daily for } 6 \text { weeks } \\
\text { Group II: amorolfine } 5 \% \text { nail lacquer } \\
\text { once weekly for } 24 \text { weeks }+200 \mathrm{mg} \\
\text { itraconazole once daily for } 12 \text { weeks } \\
\text { Group III: Itraconazole monotherapy for } \\
12 \text { weeks }\end{array}$ & 24weeks & $\begin{array}{l}\text { Mycological cure: } 93.3 \%, 82.9 \% \\
\text { and } 41.17 \% \text { in Group I, II and III, } \\
\text { respectively, in } 12 \text { weeks. } \\
\text { Complete cure: } 83.7 \%, 93.9 \% \\
\text { and } 68.8 \% \text { in Group I, II and III, } \\
\text { respectively, in } 24 \text { weeks. }\end{array}$ & $\begin{array}{l}\text { Combination therapy } \\
\text { proved to be effective in } \\
\text { severe onychomycosis. }\end{array}$ & [60] \\
\hline $\begin{array}{c}\text { Topical } \\
\text { amorolfine }+ \\
\text { oral itraconazole }\end{array}$ & $\begin{array}{l}44 \\
\text { patients } \\
\text { per } \\
\text { group }\end{array}$ & $\begin{array}{l}\text { Severe toenail } \\
\text { onychomycosis }\end{array}$ & $\begin{array}{c}\text { Group I: Amorolfine (5\%) nail lacquer } \\
\text { once weekly for } 24 \text { weeks and }+ \\
\text { Itraconazole ( } 2 \text { capsules (100mg) once } \\
\text { daily for } 6 \text { weeks } \\
\text { Group II: Amorolfine }(5 \%) \text { nail lacquer } \\
\text { once weekly for } 24 \text { weeks and }+ \\
\text { Itraconazole ( } 2 \text { capsules (100mg) once } \\
\text { daily for } 12 \text { weeks } \\
\text { Group III: Monotherapy for Itraconazole } \\
\text { for } 12 \text { weeks }\end{array}$ & 24 weeks & $\begin{array}{c}\text { Mycologic cure: } 93 \%, 83 \% \text { and } 41 \% \\
\text { in Group I, II and III, respectively at } \\
\text { week } 12 . \\
\text { Complete cure: } 84 \%, 94 \% \text { and } 69 \% \\
\text { in Group I, II and III, respectively at } \\
\text { week } 24 .\end{array}$ & $\begin{array}{c}\text { Combination therapy } \\
\text { was clinical effective and } \\
\text { cost effective. }\end{array}$ & [61] \\
\hline $\begin{array}{c}\text { Topical } \\
\text { amorolfine and } \\
\text { oral Itraconazole } \\
\text { and }\end{array}$ & 91 & Fingernails & $\begin{array}{c}\text { Group I: itraconazole pulse therapy for } \\
2 \text { months and + amorolfine } 5 \% \text { solution } \\
\text { nail lacquer for } 6 \text { months } \\
\text { Group II: Monotherapy with three } \\
\text { pulses of itraconazole }\end{array}$ & 3 months & $\begin{array}{c}\text { Mycologic cure: } 74 \% \text { and } 60 \% \text { in } \\
\text { Group I and II, respectively at } 3 \\
\text { months. } \\
\text { Complete cure: } 93 \% \text { and } 81 \% \text { in } \\
\text { Group I and II, respectively at } 9 \\
\text { months. }\end{array}$ & $\begin{array}{l}\text { Combination therapy } \\
\text { was more effective } \\
\text { in case of severe } \\
\text { onychomycosis than } \\
\text { monotherapy. }\end{array}$ & [62] \\
\hline $\begin{array}{c}\text { Topical } \\
\text { ciclopirox }+ \text { oral } \\
\text { terbinafine }\end{array}$ & 73 & $\begin{array}{l}\text { Moderate to } \\
\text { severe }\end{array}$ & $\begin{array}{c}\text { Group I: ciclopirox ( } 8 \% \text { ) once daily for } \\
48 \text { weeks }+4 \text { weeks of terbinafine } 250 \\
\text { mg/day, followed by } 4 \text { weeks of rest (no } \\
\text { terbinafine), then another } 4 \text { weeks of } \\
\text { terbinafine } 250 \text { mg/day } \\
\text { Group II: ciclopirox nail lacquer once } \\
\text { daily for } 48 \text { weeks plus terbinafine } 250 \\
\text { mg/day for } 12 \text { weeks } \\
\text { Group III: terbinafine } 250 \mathrm{mg} / \text { day for } \\
12 \text { weeks }\end{array}$ & 48 weeks & $\begin{array}{l}\text { Mycologic cure: } 66.7 \%, 70.4 \% \\
\text { and } 56 \% \text { in Group I, II and III, } \\
\text { respectively. } \\
\text { Complete cure: } 40 \%, 33.3 \% \\
\text { and } 34.8 \% \text { in Group I, II and III, } \\
\text { respectively. }\end{array}$ & $\begin{array}{l}\text { Combination therapy } \\
\text { may be an alternative } \\
\text { regimen to continuous } \\
\text { terbinafine in the } \\
\text { treatment of moderate to } \\
\text { severe onychomycosis. }\end{array}$ & [63] \\
\hline
\end{tabular}




\begin{tabular}{|c|c|c|c|c|c|c|c|}
\hline $\begin{array}{l}\text { Oral terbinafine } \\
+ \text { topical } \\
\text { ciclopirox } \\
\text { or topical } \\
\text { amorolfine }\end{array}$ & 48 & Finger and toenail & $\begin{array}{l}\text { Group I: Terbinafine } 250 \mathrm{mg} \text {, one tablet } \\
\text { twice daily for seven days every month } \\
\text { (pulse therapy) } \\
\text { Group II: oral terbinafine pulse therapy } \\
\text { + topical ciclopirox olamine } 8 \% \text { to be } \\
\text { applied once daily } \\
\text { Group III: oral terbinafine pulse therapy } \\
\text { plus topical amorolfine hydrochloride } \\
5 \% \text { to be applied once weekly for } 4 \\
\text { months }\end{array}$ & 36 weeks & $\begin{array}{c}\text { Clinical cure: } 71.73,82.60 \text { and } \\
73.91 \% \text { patients in groups I, II and III, } \\
\text { respectively. } \\
\text { Mycological cure rate: } 88.9,88.9 \\
\text { and } 85.7 \% \text { in groups I, II and III, } \\
\text { respectively. }\end{array}$ & $\begin{array}{l}\text { Combination therapy } \\
\text { with topical ciclopirox or } \\
\text { amorolfine did not show } \\
\text { any significant difference } \\
\text { in efficacy in comparison } \\
\text { to monotherapy with oral } \\
\text { terbinafine. }\end{array}$ & [64] \\
\hline $\begin{array}{c}\text { Topical } \\
\text { amorolfine and } \\
\text { oral terbinafine }\end{array}$ & 249 & Toenail & $\begin{array}{l}\text { Group I: amorolfine hydrochloride } 5 \% \\
\text { nail lacquer once weekly for } 12 \text { months } \\
+ \text { Terbinafine } 250 \text { mg once daily for } 3 \\
\text { months } \\
\text { Group II: Terbinafine alone once daily } \\
\text { for } 3 \text { months }\end{array}$ & $\begin{array}{c}18 \\
\text { months }\end{array}$ & $\begin{array}{l}\text { Complete cure rate: } 59.2 \text { and } 45 \% \text { in } \\
\text { Group I and II, respectively. }\end{array}$ & $\begin{array}{l}\text { Combination therapy } \\
\text { enhanced clinical } \\
\text { efficacy and was more } \\
\text { cost-effective than } \\
\text { terbinafine alone. }\end{array}$ & [65] \\
\hline
\end{tabular}

*Not mentioned

Table 8: Clinical trials investigating efficacy of different combination of antifungal agents.

\begin{tabular}{|c|c|c|c|c|c|c|}
\hline $\begin{array}{l}\text { No. of } \\
\text { subjects }\end{array}$ & $\begin{array}{l}\text { Site or Stage of } \\
\text { Onychomycosis }\end{array}$ & Dosage Regimen & $\begin{array}{l}\text { Follow up } \\
\text { period }\end{array}$ & Observation & Remarks & Ref. \\
\hline $\begin{array}{l}\text { Study 1: } \mathrm{N}= \\
\quad 870 ; \\
\text { Study 2: } \mathrm{N}_{2} \\
\quad=785\end{array}$ & $\begin{array}{l}\text { Distal lateral subungual } \\
\text { onychomycosis }\end{array}$ & $\begin{array}{c}\text { Group I: Efinaconazole } 10 \% \text { solution } \\
\text { once daily for } 48 \text { weeks } \\
\text { Group II: Vehicle treated }\end{array}$ & 4 weeks & $\begin{array}{c}\text { Mycologic cure: significantly } \\
\text { greater }(\sim 53 \%) \text { in Group I than } \\
\text { Group II. } \\
\text { Complete cure: } \sim 16 \% \text { in Group I } \\
\text { and } \sim 4 \% \text { in Group II. }\end{array}$ & $\begin{array}{l}\text { A viable alternative to } \\
\text { oral treatment options. }\end{array}$ & [66] \\
\hline 135 & $\begin{array}{l}\text { Distal lateral subungual } \\
\text { onychomycosis }\end{array}$ & $\begin{array}{c}\text { Group I: Efinaconazole 10\% } \\
\text { solution (with semiocclusion), } \\
\text { Group II: Efinaconazole 10\% } \\
\text { solution (without semiocclusion), } \\
\text { Group III: efinaconazole 5\% } \\
\text { solution, } \\
\text { Group IV: vehicle } \\
\text { (once daily for } 36 \text { weeks) }\end{array}$ & 4 weeks & $\begin{array}{c}\text { Mycologic cure: } 83 \%, 87 \% \text {, } \\
\text { and } 87 \% \text { in Group I, II and III, } \\
\text { respectively. } \\
\text { Complete cure: was numerically } \\
\text { higher in all active groups ( } 16 \% \text { - } \\
26 \%) \text { compared with vehicle } \\
(9 \%) \text {. }\end{array}$ & $\begin{array}{l}\text { Efinaconazole } 10 \% \\
\text { solution (with or without } \\
\text { semiocclusion) was } \\
\text { more effective than } \\
\text { vehicle. }\end{array}$ & [68] \\
\hline 1,655 & Mild to moderate & $\begin{array}{c}\text { Group I: Efinaconazole } 10 \% \text { solution } \\
\text { once daily for } 48 \text { weeks } \\
\text { Group II: Vehicle treated }\end{array}$ & * & $\begin{array}{l}\text { Mycologic cure: } 58.2 \% \text { and } \\
55.5 \% \text { in mild and moderate } \\
\text { onychomycosis, respectively, in } \\
\text { Group I and } 25.0 \% \text { and } 14.1 \% \text {, } \\
\text { respectively, in Group II. }\end{array}$ & $\begin{array}{l}\text { A useful topical option } \\
\text { in the treatment of } \\
\text { mild-to-moderate } \\
\text { onychomycosis. }\end{array}$ & [69] \\
\hline
\end{tabular}

* Not mentioned

Table 9: Clinical studies including investigation of efinaconazole $10 \%$ solution.

in other markets also like USA. A pharmacokinetic study of luliconazole, in 24 participants with moderate-to-severe DLSO of both great toenails has recently been completed. The participants applied 20 $\mathrm{mg} / \mathrm{mL}$ luliconazole, which is twice the recommended daily dose, for 29 days with a seven day follow- up. The pharmacokinetic assessment revealed that the systemic distribution of the drug was low (0.083-0.100 $\mathrm{ng} / \mathrm{ml}$ ) with the drug steady state achieved at eighth day. The drug was detected in the systemic circulation of several patients during the seven day follow-up period. The median concentration of luliconazole in the nail at this time point was $34.65 \mathrm{mg} / \mathrm{g}$ [71].

Tevaborole: Tevaborole, an oxaborole antifungal agent, is merchandised by Anacor Pharmaceuticals, CA, USA under the trade name "Kerydin". The drug got its FDA approval in 2014 for the treatment of fungal infection of the nail plate as well as of the nail bed. It acts by impeding protein synthesis of the pathogen by inhibiting the enzyme cytosolic leucyl-transfer RNA synthetase (LeuRS). The latter plays a significant role in protein synthesis pathway in the fungus. The inhibition of protein synthesis results in inhibition of cell growth and ultimately leads to eradication of fungus [72].

The topical use of tevaborole is preferred over the oral therapy so as to reduce the incidence of systemic side effects. The drug obliterates the use of debridement of the affected nail, which is often invasive and painful. The drug- drug interactions are to lesser extent in case of tevaborole as it has shown negligible inhibition of cytochrome P450 enzyme. Moreover, the safety and efficacy of the drug is found to be analogous to other available topical antifungal agents [73].

After obtaining the reasonable results from two clinical trials carried out by Ancor Pharmaceuticals, CA, USA; the findings from other multicentric analogous trials are also keenly anticipated to be sucessful. These clinical trials have imparted the advantage of assessment of systemic doses along with the different dosage forms apart from topical application. Some of them have accomplished clinical phases I and II [74]. The strong antifungal action of this drug is due to the presence of a very small element of boron in its structure. The drug possesses high patient compliance because of its topical application with negligible side effects. An extensive research is still required to ascertain the efficacy of this drug in comparison to other topical agents available.

\section{Other investigational drugs for onychomycosis}

The management of onychomycosis is a known to be a challenging endeavor owing to low cure rates and recurrence [75-80]. Due to this new molecules are gaining attraction of the researchers and subsequent clinical trials of these molecules indicate an equal investment for pharmaceutical companies. These drugs are under investigation for the treatment of onychomycosis, which vary widely from initial in vitro studies to gold-standard Phase III studies [81-84]. Table 10 enlists 


\begin{tabular}{|c|c|c|c|}
\hline Drug & Route of administration & Clinical Phase & Recommended Regimen \\
\hline Albaconazole & Oral & Phase II & Four 100 mg capsules daily for 36 weeks \\
\hline Posaconazole & Oral & Phase III & 200 mg per day \\
\hline Ravuconazole & Oral & Phase III & 200 mg per day for 12 weeks \\
\hline NB-002 and NB-00X & Topical & Phase II & $\begin{array}{c}0.5 \% \text { once daily for mild DLSO, } 0.5 \% \text { twice daily for } \\
\text { moderate DLSO and } 0.25 \% \text { twice daily for severe DLSO } \\
\text { for 42 weeks }\end{array}$ \\
\hline $\begin{array}{c}\text { TDT-067: Terbinafine in } \\
\text { Transfersome }\end{array}$ & Topical & Phase II & $1.5 \%$ TDT-067 for 12 weeks \\
\hline Terbinafine nail solution & Topical & Phase III & $10 \%$ solution for 12 weeks \\
\hline
\end{tabular}

Table 10: List of newer antifungal agents.

some these drugs which are being watch over by the clinicians for their efficacy and safety profile.

\section{Conclusion}

The stress has been laid upon by regulatory agencies on the importance of assessing the drug- dose response relationship and if possible, exposure-response relationship for the safety and effectiveness during drug development under clinical trials or even during post market surveillance/launch. The information collected from various clinical trials are defined and elaborated in the interest of patients. FDA and other regulatory agencies play a major role in clinical trial design and analysis. Various consonances are developed and set to encourage sharing of data in order to use correct drug and dose for the patients.

In case of onychomycosis, the major barriers affecting drug development for onychomycosis are the formidable barrier properties of the nail plate and an incomplete understanding of virulence factors of dermatophilic fungi, which impedes our understanding of novel drug targets. In order to achieve the complete cure and to shorten the treatment period so as to enhance the patient's compliance, extensive research is going on and still requires more efforts in order to develop new drugs and to specify their dosage regimen.

\section{References}

1. Scher RK, Baran R (2003) Onychomycosis in clinical practice: factors contributing to recurrence. Br J Dermatol 149: 5-9.

2. Speller DCE (1980) Antifungal chemotherapy. John Wiley \& Sons Ltd., Chichester, England.

3. Elewski BE (1995) Clinical pearl: diagnosis of onychomycosis. J Am Acad Dermatol 32: 500-501.

4. Elewski BE, Hay RJ (1996) Update on the management of onychomycosis: highlights of the third annual international summit on cutaneous antifungal therapy. Clin Infect Dis 23: 305-313.

5. Janssen Pharmaceutica (1997) Ketoconazole package insert. Titusville, NJ: Janssen Pharmaceutica.

6. Elewski BE (1998) Onychomycosis: Pathogenesis, Diagnosis, and Managemen Clin Microbiol Rev 11: 415-429.

7. De Doncker P (1997) Pharmacokinetics of oral antifungal agents. Dermato Ther 3: 46-57.

8. Fraki J, Heikkilä HT, Kero MO, Kuokkanen K E, Oksman RO et al. (1991) Fluconazole in the treatment of onychomycosis: an open, non-comparative study with oral $150 \mathrm{mg}$ fluconazole once weekly, Dermatology 2000 (symposium) Abstr. 14.

9. Gupta AK, Drummond-Main C, Paquet M (2013) Evidence-based optimal fluconazole dosing regimen for onychomycosis treatment. J Dermatolog Treat 24: 75-80.

10. Kuokkanen K, Alava S (1991) Fluconazole in the treatment of onychomycosis caused by dermatophytes. J Dermatol Treatment 3: 115-117.

11. Smith SW, Sealy DP, Schneider E, Lackland D (1995) An evaluation of the safety and efficacy of fluconazole in the treatment of onychomycosis. South Med J 88: 1217-1220.
12. Assaf RR, Elewski BE (1996) Intermittent fluconazole dosing in patients with onychomycosis: results of a pilot study. J Am Acad Dermatol. 35: 216-219.

13. Fraki JE, Heikkila HT, Kero MO, Kuokkanen KE, Risto O, et al. (1997) An openlabel, noncomparative, multicenter evaluation of fluconalone with or without urea nail pedicure for treatment of onychomycosis. Current Therapeutic Research 58: 481-491.

14. Scher RK, Breneman D, Rich P, Savin RC, Feingold DS, et al. (1998) Onceweekly fluconazole $(150,300$, or $450 \mathrm{mg})$ in the treatment of distal subungual onychomycosis of the toenail. J Am Acad Dermatol 38: S77-S86.

15. Hryncewicz-Gwóźdź A, Plomer-Niezgoda E, Kalinowska K, Czarnecka A, Maj $\mathrm{J}$, Jagielski T (2015) Efficacy of fluconazole at a $400 \mathrm{mg}$ weekly dose for the treatment of onychomycosis. Acta Derm Venerol 95: 251-252.

16. Matthieu L, De Doncker P, Cauwenbergh G, Woestenborghs R, van de Velde V, et al. (1991) Itraconazole penetrates the nail via the nail matrix and the nail bed an investigation in onychomycosis. Clin Exp Dermatol 16: 374-376.

17. Odom RB, Aly R, Scher RK, Daniel III CR, Elewski BE, et al. (1997) A multicenter-placebo-controlled, double-blind study of intermittent therapy with itraconazole for the treatment of onychomycosis of the fingernail. J Am Acad Dermatol 36: 231-235

18. De Doncker P, Decroix J, Pierard GE, Roelant D, Woesternborghs R, et al. (1996) Antifungal pulse therapy for onychomycosis: a pharmacokinetic and pharmacodynamic investigation of monthly cycles of 1-week pulse therapy with itraconazole. Arch Dermatol 132: 34-41.

19. Havu V, Brandt H, Heikkilä H, Hollmen A, Oksman R, et al. (1997) A double-blind, randomized study comparing itraconazole pulse therapy with continuous dosing for the treatment of toe-nail onychomycosis. Br J Dermatol 136: 230-234.

20. Doncker PD, Gupta AK, Marynissen G, Stoffels P, Heremans A (1997) Itraconazole pulse therapy for onychomycosis and dermatomycoses: an overview. J Am Acad Dermatol 37: 969-974.

21. Huang PH, Paller AS (2000) Itraconazole pulse therapy for dermatophyte onychomycosis in children. Arch Pediatr Adolesc Med 154: 614-618.

22. Firooz A, Khamesipour A, Dowlati Y (2003) Itraconazole pulse therapy improves the quality of life of patients with toenail onychomycosis. J Dermatolog Treat 14 95-98.

23. Gupta A, Lambert J, Revuz J, Shear N (2001) Update on the safety of itraconazole pulse therapy in onychomycosis and dermatomycoses. Eur Dermatol 11: 6-10.

24. Elewski BE, Scher RK, Aly R, Daniel R, Jones HE (1997) Double-blind, randomized comparison of itraconazole capsules vs. placebo in the treatment of toenail onychomycosis. Cutis 59: 217-220.

25. Goodfield MJ (1992) Short-duration therapy with terbinafine for dermatophyte onychomycosis: a multicentre trial. $\mathrm{Br} \mathrm{J}$ Dermatol 12: 33-35.

26. van der Schroeff JG, Cirkel PK, Crijns MB, Van Dijk TJ, Govaert FJ, et al. (1992) A randomized treatment duration-finding study of terbinafine in onychomycosis. Br J Dermatol 126: 36-39.

27. Nolting S, Brautigam M, Weidinger G (1994) Terbinafine in onychomycosis with involvement by non-dermatophytic fungi. Br J Dermatol 130: 16-21.

28. Ellis DH, Marley JE, Watson AB, Williams TG (1997) Significance of nondermatophyte moulds and yeasts in onychomycosis. Dermatology 194: 40-42.

29. Tausch I, Bräutigam M, Weidinger G, Jones TC (1997) Evaluation of 6 weeks treatment of terbinafine in tinea unguium in a double-blind trial comparing 6 and 12 weeks therapy. The Lagos V Study Group. Br J Dermatol 136: 737-742. 
30. Warshaw EM, Fett DD, Bloomfield HE, Grill JP, Nelson DB, et al. (2005) Pulse versus continuous terbinafine for onychomycosis: a randomized, double-blind, controlled trial. J Am Acad Dermatol 53: 578-584.

31. Tavakkol A, Fellman S, Kianifard F (2006) Safety and efficacy of oral terbinafine in the treatment of onychomycosis: analysis of the elderly subgroup in Improving Results in ONychomycosis-Concomitant Lamisil and Debridement (IRONCLAD), an open-label, randomized trial. Am J Geriatr Pharmacother 4: 1-13.

32. Takahata Y, Hiruma M, Shiraki Y, Tokuhisa Y, Sugita T, et al. (2009) Treatment of dermatophyte onychomycosis with three pulses of terbinafine $(500 \mathrm{mg}$ day for a week). Mycoses 52: 72-76.

33. Yadav P, Singal A, Pandhi D, Das S (2015) Comparative efficacy of continuous and pulse dose terbinafine regimes in toenail dermatophytosis: A randomized double-blind trial. Indian J Dermatol Venereol Leprol 81: 363-369.

34. De Backer M, De Vroey C, Lesaffre E, Scheys I, De Keyser P (1998) Twelve weeks of continuous oral therapy for toenail onychomycosis caused by dermatophytes: a double-blind comparative trial of terbinafine $250 \mathrm{mg} /$ day versus itraconazole $200 \mathrm{mg} /$ day. J Am Acad Dermatol 38: S57-63.

35. Havu V, Heikkilä H, Kuokkanen K, Nuutinen M, Rantanen T (2000) A doubleblind, randomized study to compare the efficacy and safety of terbinafine (Lamisil) with fluconazole (Diflucan) in the treatment of onychomycosis. Br J Dermatol 142: 97-102.

36. Gupta AK, Lynde CW, Konnikov N (2001) Single-blind, randomized, prospective study of sequential itraconazole and terbinafine pulse compared with terbinafine pulse for the treatment of toenail onychomycosis. J Am Acad Dermatol 44: 485-491.

37. Sigurgeirsson B, Olafsson JH, Steinsson JB, Paul C, Billstein S, et al.(2002) Long-term effectiveness of treatment with terbinafine vs itraconazole in onychomycosis: a 5-year blinded prospective follow-up study. Arch Dermatol 138: 353-357.

38. Arca E, Taştan HB, Akar A, Kurumlu Z, Gür AR (2002) An open, randomized, comparative study of oral fluconazole, itraconazole and terbinafine therapy in onychomycosis. J Dermatolog Treat 13: 3-9.

39. Piraccini BM, Sisti A, Tosti A (2010) Long-term follow-up of toenail onychomycosis caused by dermatophytes after successful treatment with systemic antifungal agents. J Am Acad Dermatol 62: 411-414.

40. Thatai P, Sapra B (2014) Transungual delivery: deliberations and creeds. Int J Cosmet Sci 36: 1-14

41. Del Rosso JQ (2014) The Role of Topical Antifungal Therapy for Onychomycosis and the Emergence of Newer Agents. J Clin Aesthet Dermatol 7: 10-18.

42. Kołodziej T, Białynicki-Birula R (2004) Ciclopirox in the treatment of seborrhoeic dermatitis. Mikol Lek 11: 329-332.

43. Subissi A, Monti D, Togni G (2010) Ciclopirox recent nonclinical and clinical data relevant to its use as a topical antimycotic agent. Drugs 70: 2133-2152.

44. Bohn M, Kraemer KT (2000) Dermatopharmacology of ciclopirox nail lacquer topical solution $8 \%$ in the treatment of onychomycosis. J Am Acad Dermato 43: S57-69.

45. Gupta AK, Fleckman P, Baran R (2000) Ciclopirox nail lacquer topical solution $8 \%$ in the treatment of toenail onychomycosis. J Am Acad Dermatol 43: S70-80.

46. Gupta AK, Joseph WS (2000) Ciclopirox $8 \%$ nail lacquer in the treatment of onychomycosis of the toenails in the United States. J Am Podiatr Med Assoc 90: 495-501.

47. Seebacher C, Nietsch KH, Ulbricht HM (2001) A multicenter, open-label study of the efficacy and safety of ciclopirox nail lacquer solution $8 \%$ for the treatment of onychomycosis in patients with diabetes. Cutis 68: 17-22.

48. Brenner MA, Harkless LB, Mendicino RW, Page JC (2007) Ciclopirox 8\% Nail Lacquer Topical Solution for the Treatment of Onychomycosis in Patients With Diabetes: A Multicenter, Open-Label Study. J Am Podiatr Med Assoc 97: 195-202.

49. Shemer A, Nathansohn N, Trau H, Amichai B, Grunwald MH (2010) Ciclopirox nail lacquer for the treatment of onychomycosis: an open non-comparative study. J Dermatol 37: 137-139.

50. Polak AM (1992) Preclinical data and mode of action of amorolfine. Clin Exp Dermatol 17: 8-12.

51. Marty JP (1995) Amorolfine nail lacquer: a novel formulation. J Eur Acad Dermatol Venereol 5:17-21.
52. Reinel D, Clarke C (1992) Comparative efficacy and safety of amorolfine nail lacquer $5 \%$ in onychomycosis, once-weekly versus twice-weekly. Clin Exp Dermatol 17: 44-49.

53. Lauharanta J (1992) Comparative efficacy and safety of amorolfine nail lacquer $2 \%$ versus $5 \%$ once weekly. Clin Exp Dermatol 17: 41-43.

54. Zaug M, Bergstraesser (1992) Amorolfine in the treatment of onychomycoses and dermatomycoses (an overview). Clin Exp Dermatol 17: 61-72.

55. Reinel D (1992) Topical treatment of onychomycosis with amorolfine 5\% nail lacquer: comparative efficacy and tolerability of once and twice weekly use. Dermatology 184: 21-24.

56. Hay RJ, Clayton YM, Moore MK (1987) A comparison of tioconazole 28\% nail solution versus base as an adjunct to oral griseofulvin in patients with onychomycosis. Clin Exp Dermatol 12: 175-177.

57. Arenas R, Fernández G, Domínguez L (1991) Onychomycosis treated with itraconazole or griseofulvin alone with and without a topical antimycotic or keratolytic agent. Int J Dermatol 30: 586-589.

58. Baran R, Feuilhade M, Combernale P, Datry A, Goettmann S, et al. (2000) A randomized trial of amorolfine $5 \%$ solution nail lacquer combined with oral terbinafine compared with terbinafine alone in the treatment of dermatophytic toenail onychomycoses affecting the matrix region. $\mathrm{Br} \mathrm{J}$ Dermatol 142: 1177 1183.

59. Baran R (2001) Topical amorolfine for 15 months combined with 12 weeks of oral terbinafine, a cost-effective treatment for onychomycosis. $\mathrm{Br} \mathrm{J}$ Dermatol 145: $15-19$.

60. Lecha M (2001) Amorolfine and itraconazole combination for severe toenai onychomycosis; results of an open randomized trial in Spain. $\mathrm{Br} \mathrm{J}$ Dermato 145: $21-26$.

61. Lecha M, Alsina M, Rodriguez JM, de Erenchun FR (2002) An open-label, multicenter study of the combination of amorolfine nail lacquer and ora itraconazole compared with oral itraconazole alone in the treatment of severe toenail onychomycosis. Curr Ther Res 63: 366-379.

62. Rigopoulos D, Katoulis AC, loannides D, Georgala S, Kalogeromitros D, et al. (2003) A randomized trial of amorolfine $5 \%$ solution nail lacquer in association with itraconazole pulse therapy compared with itraconazole alone in the treatment of Candida fingernail onychomycosis. $\mathrm{Br} \mathrm{J}$ Dermatol 149: 151-156.

63. Gupta AK (2005) Ciclopirox topical solution, $8 \%$ combined with oral terbinafine to treat onychomycosis: a randomized, evaluator-blinded study. J Drugs Dermatol 4: 481-485.

64. Jaiswal A, Sharma RP, Garg AP (2007) An open randomized comparative study to test the efficacy and safety of oral terbinafine pulse as a monotherapy and in combination with topical ciclopirox olamine $8 \%$ or topical amorolfine hydrochloride $5 \%$ in the treatment of onychomycosis. Indian J Dermato Venereol Leprol 73: 393-396.

65. Baran R, Sigurgeirsson B, de Berker D, Kaufmann R, Lecha M (2007) A multicentre, randomized, controlled study of the efficacy, safety and costeffectiveness of a combination therapy with amorolfine nail lacquer and oral terbinafine compared with oral terbinafine alone for the treatment of onychomycosis with matrix involvement. Br J Dermatol 157: 149-157.

66. Elewski BE, Rich P, Pollak R, Pariser DM, Watanabe S, et al. (2013) Efinaconazole $10 \%$ solution in the treatment of toenail onychomycosis: Two phase III multicenter, randomized, double-blind studies. J Am Acad Dermatol 68: $600-608$

67. Sugiura K, Hosaka S, Tatsumi Y, Jo W (2013) Unique properties of efinaconazole $10 \%$ solution, a new topical treatment for onychomycosis. Poster presented at 71st Annual Meeting, American Academy of Dermatology, Miami Beach FL.

68. Tschen EH, Bucko AD, Oizumi N, Kawabata H, Olin JT, et al. (2013) Efinaconazole solution in the treatment of toenail onychomycosis: a phase 2 , multicenter, randomized, double-blind study. J Drugs Dermatol 12: 186-192.

69. Rodriguez DA (2015) Efinaconazole Topical Solution, 10\%, for the Treatment of Mild and Moderate Toenail Onychomycosis. J Clin Aesthet Dermatol 8: 24-29.

70. Uchida K, Nishiyama Y, Yamaguchi H (2004) In vitro antifungal activity of Iuliconazole (NND-502), a novel imidazole antifungal agent. J Infect Chemother 10: $216-219$

71. Jones T, Tavakkol A (2013) Safety and tolerability of luliconazole solution 10-percent in patients with moderate to severe distal subungual onychomycosis. Antimicrob Agents Chemother 57: 2684-2689. 
72. Baker SJ, Zhang YK, Akama T, Lau A, Zhou H, et al. (2006) Discovery of a New Boron-Containing Antifungal Agent, 5-Fluoro-1,3-dihydro-1-hydroxy-2,1benzoxaborole (AN2690), for the Potential Treatment of Onychomycosis. J Med Chem 49: 4447-4450.

73. Gupta AK, Daigle D (2014) Potential role of Tavaborole for the treatment of onychomycosis. Future Microbiol 9:1243-1250.

74. Sharma N, Sharma D (2015) An upcoming drug for onychomycosis: Tavaborole J Pharmacol Pharmacother 6: 236-239.

75. van Rossem K, Lowe JA (2013) A Phase 1, randomized, open-label crossover study to evaluate the safety and pharmacokinetics of $400 \mathrm{mg}$ albaconazole administered to healthy participants as a tablet formulation versus a capsule formulation. Clin Pharmacol 5: 23-31.

76. GlaxosmithKline.https://www.gskclinicalstudyregister.com/compounds/ albaconazole/all/ (accessed on January 5, 2017).

77. Elewski B, Pollak R, Ashton S, Rich P, Schlessinger J, et al. (2012) A randomized, placebo- and active-controlled, parallel-group, multicentre, investigator-blinded study of four treatment regimens of posaconazole in adults with toenail onychomycosis. Br J Dermatol 166: 389-398.

78. Moore JN, Healy JR, Kraft WK (2015) Pharmacologic and clinical evaluation of posaconazole. Expert Rev Clin Pharmacol 8: 321-334.

79. Gupta AK, Leonardi C, Stoltz RR, Pierce PF, Conetta B, et al. (2005) A phase I/
II randomized, double-blind, placebo-controlled, dose-ranging study evaluating the efficacy, safety and pharmacokinetics of ravuconazole in the treatment of onychomycosis. J Eur Acad Dermatol Venereol 19: 437-443.

80. Yamaguchi H (2016) Potential of Ravuconazole and its Prodrugs as the New OralTherapeutics for Onychomycosis. Med Mycol J 57: E93-E110.

81. Pannu J, McCarthy A, Martin A, Hamouda T, Ciotti S, et al. (2009) NB- 002 a novel nanoemulsion with broad antifungal activity against dermatophytes, other filamentous fungi, and candida albicans. Antimicrob Agents Chemother 53: 3273-3279.

82. Ghannoum M, Isham N, Herbert J, William H, Sam Y (2011) Activity of TDT 067 (Terbinafine in Transfersome) against Agents of Onychomycosis, Determined by Minimum Inhibitory and Fungicidal Concentrations. J Clin Microbiol 49: 1716-1720.

83. Sigurgeirsson B, Ghannoum M (2012) Therapeutic potential of TDT 067 (terbinafine in Transfersome): a carrier-based dosage form of terbinafine for onychomycosis. Expert Opin Investig Drugs 21: 1549-1562.

84. Elewski BE, Ghannoum MA, Mayser P, Gupta AK, Korting HC, et al. (2011) Efficacy, safety and tolerability of topical terbinafine nail solution in patients with mild-to-moderate toenail onychomycosis: results from three randomized studies using double-blind vehicle-controlled and open-label active-controlled designs. J Eur Acad Dermatol Venereol 27: 287-294. 